\title{
Living Values-Based Digital Learning Resources in Civic Education
}

DOI: 10.15804/tner.2021.63.1.07

\begin{abstract}
This study seeks to analyze the students' need, the conceptual model, and generate a living values-based digital learning resource model in Civic Education. The research and development design was adopted, with the subjects being junior high school students in Bandung City and West Bandung Regency, Indonesia. The students need living values-based digital learning resources in accordance with $21^{\text {st }}$ century learning and skills. Conceptually, the model of living values-digital based learning resources is one that incorportaes living values and living values education principles into civic education learning materials through various platforms in the Moodle-based Learning Management System (LMS). The model product in the form of a Moodle-based LMS contains teaching materials, living values, media, discussion forums, assignment uploads, and evaluation for the civic education. The model is thought to develop student's character.
\end{abstract}

Key words: civic education, digital learning resources, learning management system, living values

\section{Introduction}

The Fourth Industrial Revolution has changed society and the workforce, relying on the „internet of things” (Kearney, 2016). This revolution is also referred to as the 4.0 literacy era (Aoun, 2017). This era gave birth to a generation of „digital natives", namely a generation who was born and grew up in the world of digital 
technology. This brings the challenge of increasingly waning national character among the younger generation due to disorientation and the absence of Pancasila (Indonesia's Five Principles) values, shifting ethical values in national and state life, fading awareness of national cultural values, threats of national disintegration, and weakening of national independence. Such phenomena have directly brought about the problems in our education today (Prensky, 2001; Komalasari \& Rahmat, 2019).

Therefore, it is necessary to optimize the nation's character education through formal education in schools, especially in civic education as a subject that upholds the mission of educating the Indonesian nation's life through „value-based education" and as a vehicle for nation and character building. Among the important components of civic education are learning resources, i.e. resources employed by teachers, either separately or in combination, for teaching and learning purposes with the aim of elevating the effectiveness and efficiency of learning objectives. (Komalasari \& Sapriya, 2016; Komalasari \& Saripudin, 2017).

Learning resources should be based on information and communications technology (ICT) according to the demands of $21^{\text {st }}$ century learning, i.e. fostering $21^{\text {st }}$ century skills (life and career skills, innovative-creative thinking, and mastery of ICT), and digital natives characteristics. The learning process of these digital natives requires a distinct approach. Learning and learning resources should be technology-based, a combination of processes and tools to solve learning problems by emphasizing the application of the latest computers and technologies. A broad range of technology-based learning resources in a variety of formats gives rise to the possibility of making a profound difference in education (Hill \& Hannafin, 2001; Roblyer, 2003; Trilling \& Fadel, 2009).

It is, therefore, imperative to develop digital learning resources, namely a combination of hardware (processing, memory, input and communication) and software (operating systems and application programs) which may solve learning problems and facilitate learning activities (OECD, 2009). However, in school reality, the teachers and textbooks serve as the major learning resources. Even if digital learning resources are employed, they are only confined to cognitive knowledge, inept in nurturing student character (Komalasari \& Saripudin, 2018). For this reason, it is crucial to reconstruct learning resources that have the following characteristics: 1) digital learning resources (ICT-based); 2) contextual and comprehensive learning resources (developing attitudes, higher-order thinking skills, and practical skills); 3) living values-based learning resources underpinned by the values of Pancasila, national culture, and local wisdom; and 4) learning resources that contain moral knowledge, moral feeling, and moral action as a whole. All of these characteristics must be incorporated into civic learning resources through a living values-based 
digital learning resource model as part of inculcating student character. Thus, a living values-based digital learning resource model in civic education is needed.

\section{Problem of Research}

The research problems are formulated as follows: (1) To what extent do the students need living values-based digital learning resources in civic education? (2) What is the conceptual model of living values-based digital learning resources in civic education? And (3) What is the model design of living values-based digital learning resources in civic education?

\section{Methodology of Research}

\section{General Background of Research}

Borg and Gall's (2003) Research and Development design was adopted to produce the living values-based digital learning resources model. A survey method was used to identify the student needs for the values-based digital learning resources in civic learning, and an exploratory method was utilized to discover a conceptual model and develop the model.

\section{Sample of Research}

The project took place in Bandung City and West Bandung Regency High Schools, West Java, Indonesia with the research subjects being students of state junior high schools (henceforth SMPN) 5 Bandung, SMPN 12 Bandung, SMPN 29 Bandung, SMPN 1 Lembang, dan SMPN 2 Cileunyi with a total of 1307 students, and 12 civic education teachers.

\section{Instrument and Procedures}

The data collection techniques are (1) questionnaire; (2) observation; (3) interview; and (4) focus group discussion. The research procedure utilized Step 1 to 3 of the ten steps of Borg and Gall's: Research and information collecting, planning, and developing a preliminary form of the product.

\section{Data Analysis}

A qualitative data analysis was conducted to develop the conceptual model and initial product, it included: (1) conducting data reduction; (2) systematically 
arranging data based on certain categories and classifications; (3) making data display in the form of tables or figures; (4) conducting a cross-site analysis; and (5) presenting findings, drawing conclusions in the form of general trends and the implications of their application, and proposing recommendations for development (Fraenkel \& Wallen, 2008). Meanwhile, a quantitative analysis was undertaken to quantify the questionnaire results using a quantitative descriptive method (Creswell, 2012) in identifying the student's needs for the model in question.

\section{Results of Research}

\section{Student Needs Analysis For Living Values-Based Digital Learning Resources}

This needs analysis is the stage of determining features in the digital resource model according to the needs through a survey of 1307 junior high school students scattered in Bandung City and West Bandung Regency, West Java, Indonesia (Sommerville, 2011). The results of the survey on the students' needs for digital learning resources can be seen in table 1 .

Table 1. Student needs analysis for living values-based digital learning resources $(\mathrm{N}=1307)$

\begin{tabular}{|c|c|c|c|c|c|c|c|}
\hline \multirow[b]{2}{*}{ No } & \multirow[b]{2}{*}{$\begin{array}{l}\text { Stu- } \\
\text { dent } \\
\text { need }\end{array}$} & \multirow[b]{2}{*}{ Type of need } & \multicolumn{5}{|c|}{ Scale $(\%)$} \\
\hline & & & 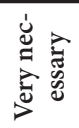 & 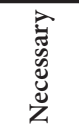 & 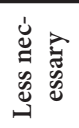 & 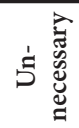 & 离离 \\
\hline \multirow[t]{6}{*}{$\bar{A}$} & \multirow{6}{*}{$\begin{array}{l}\text { Use of } \\
\text { digital } \\
\text { learn- } \\
\text { ing re- } \\
\text { sourc- } \\
\text { es }\end{array}$} & $\begin{array}{l}\text { 1. Social media (Instagram. Facebook, } \\
\text { WhatsApp) }\end{array}$ & 52.1 & 20.7 & 23.3 & 2.9 & 1.0 \\
\hline & & 2. Websites (blog, Wikipedia, WordPress) & 52.9 & 18.5 & 25.2 & 2.8 & 0.6 \\
\hline & & 3. YouTube & 60.4 & 19.4 & 18.2 & 1.8 & 0.2 \\
\hline & & 4. Podcasts & 55.5 & 8.2 & 32.0 & 3.7 & 0.6 \\
\hline & & $\begin{array}{l}\text { 5. Learning apps: Ruangguru, Ruangbe- } \\
\text { lajar, Quipper, and Zenius }\end{array}$ & 58.6 & 20.1 & 18.7 & 1.9 & 0.7 \\
\hline & & Mean scores & 55.9 & 17.4 & 23.5 & 2.6 & 0.6 \\
\hline \multirow[t]{4}{*}{ B } & \multirow{4}{*}{$\begin{array}{l}\text { Living } \\
\text { values } \\
\text { devel- } \\
\text { op- } \\
\text { ment }\end{array}$} & $\begin{array}{l}\text { 1. understanding and application of the } \\
\text { values of life }\end{array}$ & 53.8 & 32.0 & 13.5 & 0.7 & 0 \\
\hline & & $\begin{array}{l}\text { 2. integration of life values into digital } \\
\text { learning resources }\end{array}$ & 44.8 & 38.1 & 14.2 & 2.2 & 0.7 \\
\hline & & 3. variation in the use of digital platforms & 52.3 & 32.5 & 13.7 & 1.5 & 0 \\
\hline & & Mean scores & 50.3 & 34.2 & 13.8 & 1.5 & 0.2 \\
\hline
\end{tabular}


Based on the data above, two things are of interest: 1) most of the students (55.9\%) felt that digital learning resources were very necessary, with their most preferred types being YouTube and learning applications; 2 ) the majority (50.3\%) perceived that the development of living values in the form of understanding and application integrated in a variety of digital learning platforms was very necessary. The students seemed to exhibit some interest in digital learning resources such as LMS which include text, audio, audio visual and interactivity. Among the desired forms are teaching materials uploaded on the LMS, learning materials with sources from YouTube, podcasts, and social media.

\section{The Conceptual Model of Living Values-Based Digital Learning Resources in Civic Education}

Based on the results of needs analysis and focus group discussions with experts (learning resources and digital learning experts) and practitioners (civic education teachers), the conceptual model of living values-based learning resources in civic education consists of the following components:

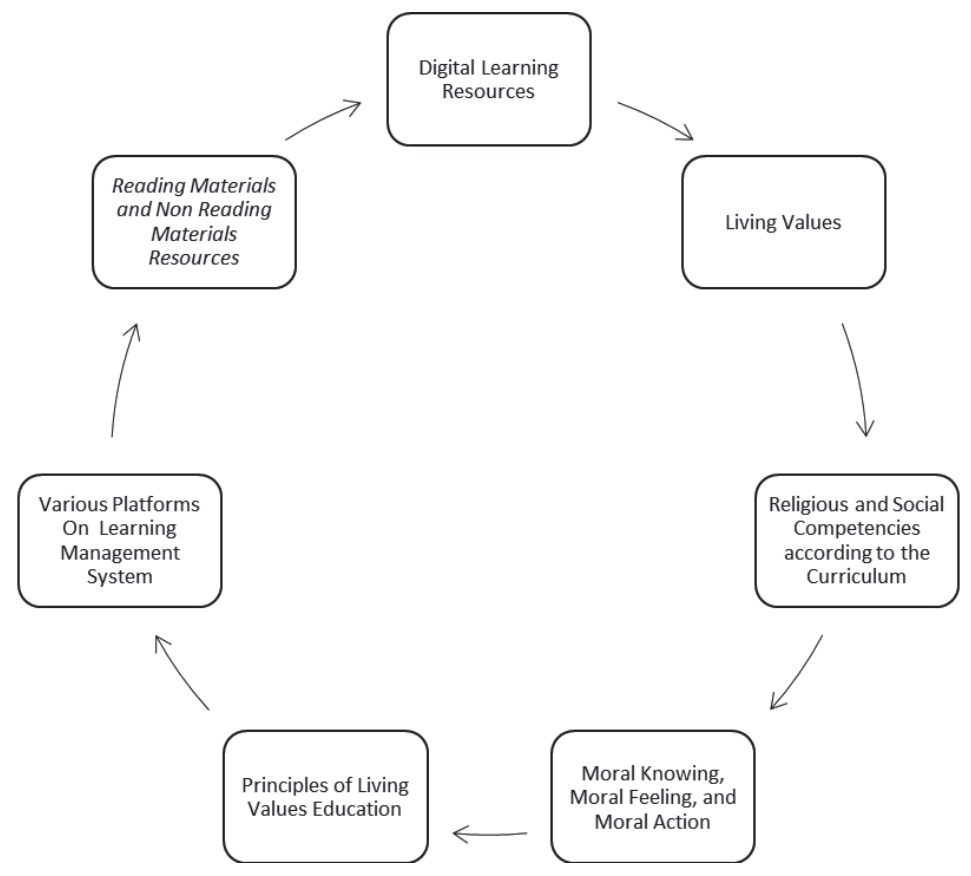

Figure 1. The components of living values-based digital learning resources 
1. Meeting the demands of $21^{\text {st }}$ century learning, i.e. a combination of hardware (processing, memory, input and communication) and software (operating systems and application programs) elements (OECD, 2009);

2. Integrating the values of life, namely the 12 values of life (Peace, Respect, Love, Responsibility, Happiness, Cooperation, Honesty, Humility, Tolerance, Modesty, Freedom and Unity) into digital learning resources (Tillman, 2004);

3. Developing core competencies for religious attitudes and social attitudes according to the curriculum by utilizing digital learning resources, not just content knowledge and skills.

4. Developing the values of life in the moral aspects of knowing, moral feeling, and moral action in a comprehensive manner (Lickona, 2013);

5. Using the principles of living values education, namely: 1) collecting points of reflection; 2) imagining; 3 ) practicing relaxation and focus; 4) expressing art; 5) fostering social skills, cognitive awareness about justice, and social harmony; and 6) collecting cultural values (Tillman, 2004; Saripudin \& Komalasari, 2015);

6. Using a variety of platforms integrated into the LMS that is attractive, in line with student's needs, and effective in attaining goals;

7. Using variations: (1) reading materials and resources including textbooks, encyclopedias, reference books, magazines, pamphlets, and newspapers; and (2) nonreading materials and resources including pictures, films, recordings, excursions, and community sources (Jarolimek, 1986).

\section{The Model Design of Living Values-Based Digital Learning Resources in Civic Education}

The design of the product was tailored to the students' interests and needs for digital learning resources in the form of an LMS which incorporates text, audio, audio visual and interactivity. The teaching materials were uploaded on the LMS system, and the learning materials were linked to YouTube, podcasts, and social media. Living values were integrated in designing scenarios for creating learning videos that contain text, audio-visual and interactivity. The learning videos were then made available on the YouTube platform, podcasts and social media for the needs of learning applications (LMS). HTML, PHP and MYSQL programming languages were used. The LMS was manufactured through various stages, namely the product design stage, the material development stage, and the product manufacturing stage as follows.

1. Product design stage 
The results of the needs analysis serve as the foundation for the general description and concept of learning resources which will be outlined in the form of flowcharts, sketches and storyboards. The learning resources were arranged into features of teaching materials, media content, discussion forums, task uploads and evaluations through a Moodle-based LMS.

a. Flowchart

The following are the steps for developing living values-based digital learning resources:

1) creating an LMS with the contents that suit the needs;

2) creating a menu consisting of a homepage, teaching materials, media, discussion forums, tasks and quizzes;

3) classifying the learning materials per grade;

4) setting up the links of media contents: videos to YouTube, voices to podcasts, posters and narrative stories;

5) uploading the tasks to the LMS system to be later assessed by the teacher;

6) grading the quiz in the quiz menu arranged by class according to the subject matter.

In the quiz menu, there is an interactive quiz where the user can answer and then find out the score of the quiz.

The flowchart is schematized as can be seen in figure 2 .

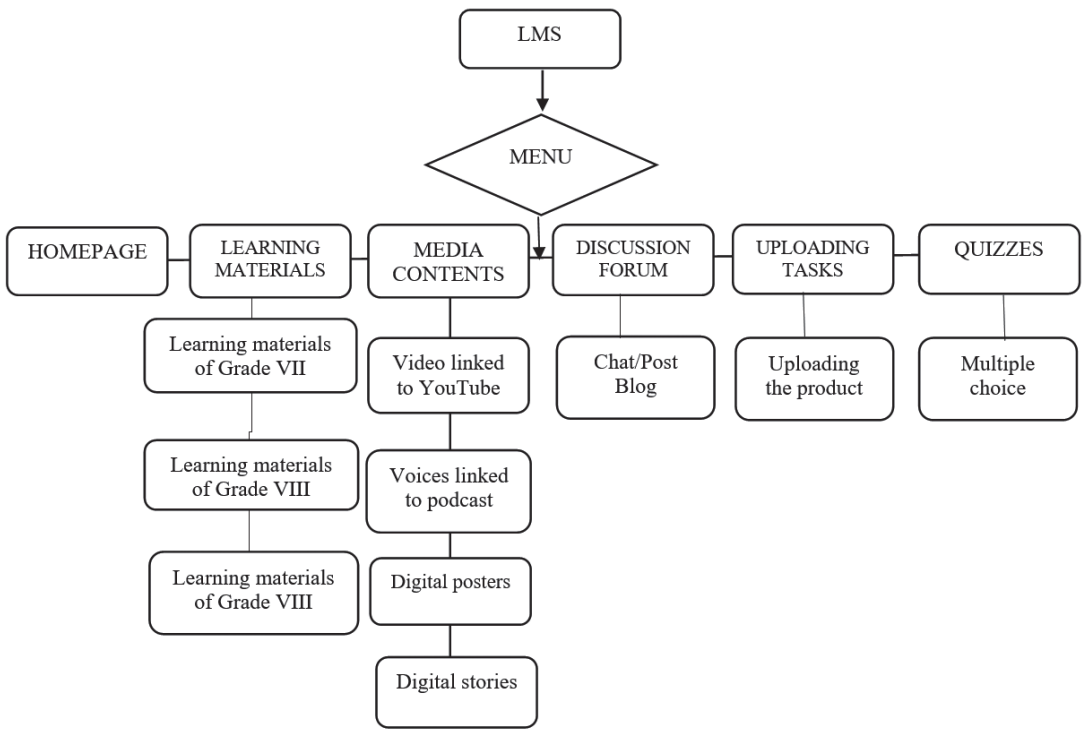

Figure 2. Flowchart of developing living values-based digital learning resources in LMS 
b. Website Display Sketch

After designing the website page flowchart, the next stage was preparing the sketch of the website display considering the results of the analysis of student needs. The menu on the LMS homepage includes: learning materials, media, discussion forums, tasks and quizzes.

c. Storyboard

Storyboards were used to visually illustrate the design of digital learning resources under examination.

2. Material development stage

In this stage, the material indicators on the living values-based digital learning resources model were produced. The steps for developing the materials include 1) the materials were designed based on the curriculum;2) the materials were prepared based on grade levels (Grade VII, VIII, and IX); 3) the materials were contextually formulated; 4) authentic tasks were incorporated to elevate students' critical thinking; and 5) various relevant media were integrated such as images, sounds, videos, posters and stories.

3. Product manufacturing stage

There are five substages as follows.

a. Analysis. In the early stages of manufacturing, a user interface using the programming languages of PHP, JavaScript and HTML and database management using MySQL was produced.

b. Creating a User Interface (Design) tailored to the age level of the user, namely junior high school students. The interface is composed of the following:

1) The web page in this application consists of several parts, including the homepage, the output of the web service;

2) The material search page contains data in XML format containing civic materials;

3) The media search page contains data in XML format which contains videos, podcasts, posters, and stories that provide a range of choices on the subject matter;

4) A discussion forum search page in the form of a chat forum to allow for live and interactive communication between students and teachers. Apart from chats, students can initiate blog posts or comment on other students' posts.

5) Task search page where students can upload assignments in a pdf or word form with a limited capacity of up to $10 \mathrm{mb}$. The teacher can later grade student assignments and provide feedback; 
6) The quiz search page contains data in swf format as a learning evaluation tool. The quiz in the form of interactive multiple-choice questions can be answered directly by students. Links to the materials/concepts are also available.

c. Coding of the objects in the interface using the Integrated Development Environment (IDE) programming language, in addition to several script languages such as html, java script used in the learning multimedia.

d. Testing the media to check whether the code in the learning resources operates properly, locate deficiencies that must be corrected, and spot errors that can cause the multimedia to malfunction.

e. Implementation of the use of digital sources. The file generated from the testing phase has an exe extension, so that all Windows operating systems can easily open the file.

\section{Discussion}

The key findings from the present reseach can be elaborated as follows. First, the living values-based digital learning resources offer a new learning format whereby life values are integrated in the subject matter and presented through LMS. This has made a profound difference in educational practices over the years (Hill \& Hannafin, 2001). Not only do digital learning resources transmit and access information, but they enable learners to construct materials that provide ample opportunities to create and express themselves (Resnick, 2002).

Second, the living values-based digital learning resources model proposed in this research was produced with the waterfall model information management system as it provides the ability for visualization, simulation, games and interactivity. The use of digital learning resources has had an impact on increasing motivation, retention, learning styles, creativity, and learning quality (BECTA, 2007), leading to fun learning activities. The learning process includes computer self-efficacy, teaching experience, computer technology support, teacher pedagogical practice and professional development in integrating technology (Bingimlas, 2009; Gilakjani, 2013).

Third, the integration of living values into digital learning resources in civic learning is a new breakthrough, where digital learning resources can unveil a range of new digitalization habits that universally underlie good and harmonious relationships between users. These are habits that we may find difficult in our times today and in the future, sidelined by the individualistic, hedonistic and 
materialistic attitudes and traits of modern humans; forgetting that we are social, virtuous and moral beings (Arweck \& Nesbitt, 2004). This phenomenon gives birth to new humans with new needs. Prensky (2001) refers to the current generation as "digital natives", namely a generation that was born and raised in the midst of digital technology. Therefore, teaching digital natives requires a set of different approaches. To this end, educational technology needs to carry out self-assessment (Seel \& Richey, 1994; Reiser \& Ely, 1997).

Fourth, numerous factors affect the use of technology in the learning process including computer self-efficacy, teaching experience, computer technology support, teacher pedagogical practices and professional development in integrating technology (Gilakjani, 2013; Bingimlas, 2009). Positive changes can be made in the educational process for teachers to use technology in learning.

Fifth, there is a need for digital competence of educators which is closely tied to the skills of using information and communication technology based on pedagogical principles by considering appropriate educational methodologies. Educators' digital competencies fall into several forms, namely: information, communication, educational content creation, security, educational problem solving (Blyznyuk, 2018).

1. Information, data literacy skills (the ability to locate, select, sort, evaluate, manage information suited for learning);

2. Communication, the ability to interact, engage, share and cooperate through digital technology;

3. Educational content creation, the ability to create digital learning contents (e.g. learning application programs, interactive presentations, and learning animations).

4. Security, the ability to ensure protection against the impact of technology products for students in the learning process.

5. Educational problem solving, the ability to overcome technical problems, to identify the technological responses and needs in learning, to identify the shortcomings of digital technology in learning, and to positively utilize technological products in learning.

\section{Conclusions}

The living values-based digital learning resources model in this research was tailored according to students' needs for effective learning resources in the digital era to achieve learning goals and foster living values. The model in question 
integrates the values of life and the principles of living values education into civic education learning materials through various platforms in the Moodle-based LMS. The system constituted teaching materials and living values, media, discussion forums, task uploads, and evaluation. This digital learning model is expected to hone student character.

\section{Acknowledgements}

This study was supported by a grant from the Indonesia Ministry of Research, Technology and Higher Education. The authors would like to express sincere appreciation for all the support provided.

\section{References}

Aoun, J.E. (2017). Robot-Proof: Higher Education in the Age of Artificial Intelligence. United States: Massachusetts Institute of Technology (MIT).

Arweck, E. \& Nesbitt, E. (2004). Living Values: An Educational Program from Initiative to Uptake. British Educational Research Journal, 26(2), 133-149.

BECTA (British Educational Communications and Technology Agency). (2007). Harnessing technology schools survey. Retrieved 04/10/2013. From http://dera.ioe.ac.uk/1554/1/ bect a_2007_htssfindings_report.pdf.

Bingimlas, K.A. (2009). Barriers to The Successful Integration of ICT in Teaching and Learning Environments: A Review Of The Literature. Eurasia Journal of Mathematics, Science and Technology Education, 5(3), 235-245. DOI:10.12973/EJMSTE/75275

Blyznyuk, T. (2018). Formation of Teachers Digital Competence: Domestic Challenges and Foreign Experience, Journal of Vasyl Stefanyk Precarpathian National University, 5(1), 40-46. DOI: 10.15330/jpnu.5.1.40-46

Borg, W.R., \& Gall, M.D. (2003). Educational Research: An Introduction (5 ${ }^{\text {th }}$ ed). New York: Longman.

Creswell, J.W. (2008). Educational Research: Planning, Conducting, and Evaluating Quantitative and Qualitative Research, New Jersey: Pearson Education, Inc.

Fraenkel, J.R. \& Wallen, N.E. (2008). How to Design and Evaluate in Research. New York: The McGraw-Hill Companies, Inc.

Gilakjani, A.P. (2013). Factors Contributing to Teachers' Use of Computer Technology in the Classroom. Universal Journal of Educational Research, 1(3), 262-267. DOI: 10.13189/ ujer.2013.010317

Hill, J.R. \& Hannafin, M.J. (2001) Teaching and learning in digital environments: The Resurgence of Resource-Based Learning. Educational Technology Research and Development 49(3), 37-52.

Jarolimek, J. (1986). Social Studies in Elementary Educations (7th Ed). New York: Mac. 
Kearney, A.T. (2016). Global Retail Expansion at A Crossroads-2016 GRDI. Retrieved 10/05/2016 from https://www.atkearney.com/consumer-products-retail/global-retaildevelopment-index

Komalasari, K \& Sapriya. (2016). Living Values Education in Teaching Materials to Develop Students' Civic Disposition, The New Educational Review, 44(2), 107-124. DOI: 10.15804/tner.2016.44.2.09.

Komalasari, K, \& Saripudin, D. (2017). Value-Based Interactive Multimedia Development through Integrated Practice for The Formation of Students' Character, Turkish Online Journal of Educational Technology 16 (4), 179-186.

Komalasari, K \& Saripudin, D. (2018). The Influence of Living Values Education-Based Civic Education Textbook on Student's Character Formation, International Journal of Instruction, 11 (1), 395-410. DOI: 10.12973/iji.2018.11127a

Komalasari, K \& Rahmat. (2019). Living Values Based Interactive Multimedia in Civic Education Learning, International Journal of Instruction, 12(1), 113-126. DOI: 10.29333/ iji.2019.1218a.

Lickona, T. (2013). Educating for Character How Our Schools Can Teach Respect and Responsibility. New York-Toronto-London-Sydney-Auckland: Bantam Books

OECD (Organisation for Economic Cooperation and Development). (2009). Beyond Textbooks; Digital Learning Resources as Systemic Innovation In The Noordic Country. Retrieved 29/09/2014 from http://browse.oecdbookshop.org/oecd/pdfs/product/9609081e.pdf

Prensky, M. (2001). Digital Natives, Digital Immigrants, Part 1. On The Horizon, 9(5), 3-6. DOI: $10.1108 / 10748120110424816$

Reiser, R.A., \& Ely, D.P. (1997). The Field of Educational Technology as Reflected Through Its Definitions. Educational Technology, Research and Development, 45(3), 65-74.

Resnick, M. (2002). "Rethinking learning in the digital age" in G. Kirkman (Ed.) In The Global Information Technology Report: Readiness for the Networked World (pp. 32-37). Oxford University Press.

Roblyer, M.D. (2003). Integration Educational Technology into Teaching. Columbus, Ohio. Saripudin, D. \& Komalasari, K. (2015). Living Values Education in School's Habituation Program and Its Effect on Student's Character. The New Educational Review 39(1), 51-62. DOI: 10.15804/tner.2015.39.1.04

Seels, B.B. \& Richey, R.C. (1994) Instructional Technology: The Definition And Domains Of The Field. AECT, Washington DC.

Sommerville, I. (2011). Software Engineering (9 $9^{\text {th }}$ Edition). USA, Pearson.

Tillman, D. (2004). Living Values: Activities for Children Ages 8-14. Jakarta: PT Gramedia Widiasarana Indonesia.

Trilling, B. \& Fadel, C. (2009). $21^{\text {st }}$ Century Skills: Learning for Life in Our Times, John Wiley \& Sons. 